\title{
EXAMINATION OF THE HUNGARIAN ESPORT ECOSYSTEM THROGH INTERNATIONAL EXAMPLES
}

\author{
${ }^{1}$ Anikó Molnár, ${ }^{2}$ János Sánta, ${ }^{3}$ Gergely Gábor Ráthonyi \\ University of Debrecen \\ ${ }^{1}$ Institute of Rural Development, Tourism and Sports Management \\ ${ }^{2}$ Computer Science Engineering \\ ${ }^{3}$ Institute of Applied Informatics and Logistics \\ ${ }^{1}$ miller.e.annie@gmail.com \\ 2janos.santa87@gmail.com \\ 33rathonyi.gergely@econ.unideb.hu
}

\begin{abstract}
Esport was very close to be medal awarded competition at the 2022 Asian Games, finally esport excluded from the Asian Games but all is not lost that is delayed. We have come a long way since the first real esport tour-nament, for which the first-place prize was a year-long Rolling stone maga-zine subscription. Nowadays in the digitalized world esport develops faster than any other sport, and plays an important role in the entertainment in-dustry as well. Stadiums are crowded, streams are watched by millions worldwide, and the pace doesn't seem to ease up in the future either. As Hungary is trying to step onto international waters, our main goal was to make a comprehensive review of the Hungarian esport ecosystem analyz-ing the national picture of electronic sport. Although there is not much do-mestic literature regarding the topic, as a secondary research we choose to use available Hungarian papers to piece together a comprehensive picture. We move on step by step through the biggest stakeholders: the publishers, the biggest domestic competitions, the most successful players, platforms, brands and of course the fans in domestic circles.
\end{abstract}

Keywords: esport; esport ecosystem; Hungarian esport; national review

(JEL Classification: Z29)

\section{INTRODUCTION}

ESPORT is a fairly "new" worldwide phenomenon with its first ever docu-mented tournament dating back to the early seventies. Esport cultivated its first generation of esport players from the Computer Science majors of the University of Stanford and there was no turning back since then. Although the fast development of esport was advanced with such milestones as the internet and world wide web uptake in the late nineties, which connected the players on a global scale, the most dynamical phase of its development started in the 2010's. Because of its fairly newness, esport still hasn't reached its full potential, but is entering a new phase toward becoming a mature market (NEWZOO, 2017).

Because of these reasons in particular we believe it is important to analyze and understand its general rules, processes and its nature.
First of all, let's see what does esport exactly mean. It is important to point out, that a generally accepted definition of esports does not exist (OLSEN, 2015). The collected literature has and uses multiple definitions to describe this activity.

In order for our research framework to develop we took into account the most used definitions and analyzed its meeting points, from which we identified 3 major criteria for esports to be characterized by. From these key points esport can be described by the following: an activity performed in virtual environment in competitive settings in which people develop and train physical and/or mental abilities.

The analyzation of the definitions outlined a possible answer to a widely debated problem in literatures and esport subcultures as well: Does esport considered as sport?

Looking at the definition of sport in Article 2 of the European Sport Char-ter: "Sport" means all forms of physical activity which, through casual or organized participation, 
aim at expressing or improving physical fitness and mental well-being, forming social relationships or obtaining results in com-petition at all levels. (EUROPEAN SPORT CHARTER, 1997).

The viewpoint of those favorizing the game suggests that esport reflects the main aspects of sports such as interpersonal competition, development of skills and abilities, the enforcement of rules, attainment of goals, and even levels of coordination and agility (CRAWFORD and GOSLING, 2009).

The criteria taken from the definitions discussed above, compared to the definition of the Sport Charter, suggests that the main essence of sport such as competitive activity, improving physical and mental fitness and achiev-ing results at different levels of competition are all in line with the definition of the Charter. On this basis, in the next stages of our research, we consider electronic sport as a sport and examine it accordingly.

\section{BRIEF HISTORY OF ESPORTS IN HUNGARY}

The first signs of the todays known esport in Hungary appeared in 1990-'93, when a television show called "Elektor Kalandor" in which Super Mario could be played on NES (Nintendo Entertainment System) consoles started to captivate the home screens (PWC, 2018).

The first bigger esport series started in 2000 named as EarthQuake with sponsors like Samsung and the World Cyber Games, later on even renamed after it as World Cyber Games Hungary. As Counter Strike got to left out the series started to lose its popularity. It didn't disappear completely how-ever, and went on as the Budapest Game Show, after another name change, it took its present form in the form of PlayIT, held every year (FLANCHER, 2019).

Other esport events started to emerge such as qualifier of the Electronic Sports World Cup, the Gody LAN in 2005, the BECUP in 2007, and ICL in 2009 (FLANCHER, 2019).

The breakthrough came with the cooperation of PlayIT and the Esportmilla (One million people for the Hungarian Esport movement). Because of this agreement PlayIT started to incorporate esport competitions to its program. Due to the rising popularity of these competitions they organized the first esport focused event the Esport Fest.

In 2017 the Hungarian Government decided to give 2 billion Huf to the Eportmilla for an esport championship and conference to be organized (FLANCHER, 2019). The main goal was to bring the international esport closer to the countries of the Visegrád Four (Czech Republic, Hungary, Poland and Slovakia).

The V4 Future Sports Festival was very useful in that it drew attention to esports in the region and showed that this can be done in Hungary as well, it became clear that there is a willingness to cooperate at regional and even European level, for example by bringing together different associations (FLANCHER, 2019).

After the event it also became evident, that in order for Hungarian teams to catch up to the international level a structural base is necessary.

To support this idea traditional sport clubs started to integrate esport teams in to their clubs or formed new esport departments.

After this the next step was the establishment of the HUNESZ (Hungarian E-sport Federation) in august 2018, which main goal was to bring together these organizations and to help participants to enter the esport market (FLANCHER, 2019).

Up until today their most important achievement was undoubtedly the launch of Hungary's first multi-game league series, the Hungarian National Sports Championship last September, where teams could compete in five different games (League of Legends, Counter-Strike: Global Offensive, PlayerUnknown's Battlegrounds, Hearthstone, Rainbow Six Siege).

With this Championship the aim shifted to the structural base, as the main goal was to bring in stability.

It is very clear that Hungary is definitely on its way to help the national esport scene to grow.

\section{MATERIAL AND METHOD}

From the brief history it is evident, that because the development of Hun-garian is fairly recent esport is only starting to get recognition. The lack of literature of Hungarian esport supports this fact too, as up until 2016, there was almost no official research in Hungary with data and details on the esport market (SZABELLA, 2018). For us to see the differences from the major esport powers we need to get a clear national picture. Now as it was mentioned before there are only a few researches. In our research we col-lected these existing papers and our main goal was to get a relatively complete review of the national esport's situation. As a secondary research we used the method of document analyzation with which we studied national and international literatures as well.

To get qualitative datas we analyzed the national esport market report of the PricewaterhouseCoopers as well as the national survey of eNet.

\section{RESULTS}

In order for us to analyze the key components of the Hungarian esport ecosystem we need to take a look at the overall picture and understand its networks and processes. Figure 1. shows the main model of the ecosystem.

Figure 1. The model of the Hungarian Esport Ecosystem

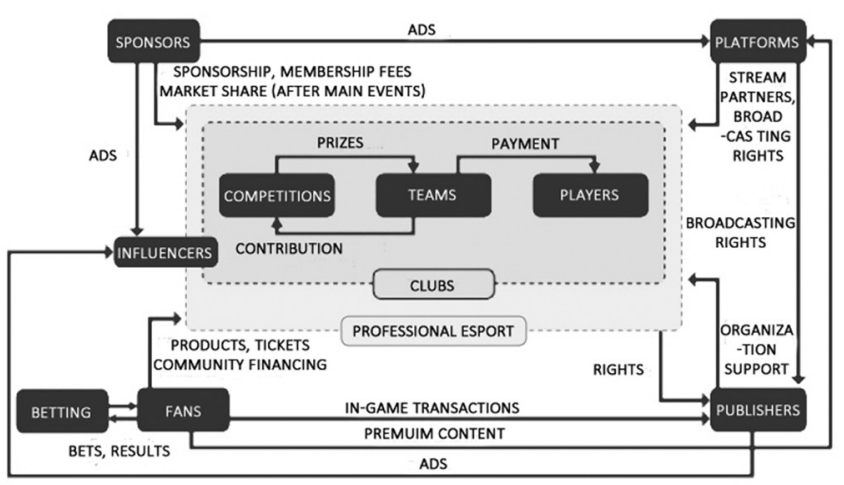

Source: Own editing based on PwC (PWC, 2018) 
The six key components of the model are the game publishers, the media platforms, the players and teams, the competitions, the sponsors and the fans.

Each and every components or "participants" has their own revenue. The heart of the ecosystem are the players/ teams. Without them there wouldn't be a content to watch or follow. Another key element is the competitions as they are the main subjects of esport. We can not forget about the game publishers either as they provide the games, they sell the competition and broadcasting rights so their role in the whole ecosystem is decisive. With the publisher's games through competition players make content. And with platforms contents (such as competitions, streams and analyses) reach the viewers (PWC, 2018).

\section{The Publishers}

The most involved Publishers in Hungary are Riot Games, Valve Corpora-tion and Blizzard Entertainment. With the unbreakable popularity of League of Legends (61\%) the top 5 most popular esport games in 2018 were: Riots: LoL, Valve's: Counter-Strike: Global Offensive (49\%), Blizzard's: Hearthstone (38\%), PUBG Corp's Playerunknown's BattleGrounds (35\%) and Electronic Arts': FIFA (20\%) (ENET, 2019a and 2019b).

As from the statistics can be seen we get a colorful picture regarding the genres of the most popular games, from CS: GO's and PUBG's FPS (First person shooter) games, to the best of MOBA (Multiplayer online battle arena) namely the LoL, and sport games like FIFA.

\section{Broadcastings}

From the aspect of the ecosystem platforms play a role of great importance as they are the link between the players/ teams and the viewers. They also serve as the main channel for media contents to be streamed and as a mar-keting and sponsorship tool as well.

Besides being a revenue provider by streaming players contents, this new media type helped the evolution of esports by opening a new and easier way of talents to be discovered.

In Hungary the population of these platforms follows the international trends closely.

In domestic circles the most popular is the game stream market leader Twitch.tv. Since its establishment in 2011 the numbers of monthly viewers reached 100 million (Needleman, 2015). And in January 2019 alone 63700 people streamed 1.9 million hours of live video content (PANNEKEET, 2019).

The websites main attractions are that its completely free, it provides the viewer live rankings regarding the currently most viewed events. Thus, can be used, to find the most popular titles and events and streams as well.

Besides Twitch.tv the Google LLC. owned YouTube entered the market as well. From Google's unsuccessful attempt to buy Twitch in 2014 the con-currence is evident in trying to up Twitch's viewership. By streaming live esport content in its website Google combines You tube's traditional video services with esport streaming. Although not as effective as its counterpart it seems to be working as in January 201922
000 people streamed on YouTube, producing 460000 hours of live content (PANNEKEET, 2019).

On the third step of the podium is Facebook. In 2017 Facebook made an agreement with Electronic Sports League (ESL) to stream 5500 hours of esports content to its users (NEEDLEMAN and SEETHARAMAN, 2017). With its 2.41 billion monthly active users (NOYES, 2019) Facebook and ESL seems to be on the right track to reach more and more people. And to top it all they didn't agree on exclusivity, thus besides reaching into new grounds ESL still uses other platforms as well.

Besides connecting the players, their contents and the viewer the network and connectivity of the platforms extends through ads to the sponsors and with broadcasting rights to the publishers as well.

\section{The Players and Teams}

The eNets latest esport survey shows that the number of videogame players in Hungary reaches the $60 \%$ of the total population. Although at first glance the 3.7 million players seem a lot, it is because of the wider interpre-tation of the definition of videogame players. It includes those who play casually at least once a week and either on PC, on mobile phone, or on other type of consoles, either online or offline. The demographic picture also shows that the most active age group with $66 \%$ participation is be-tween 18 and 25. And although men are more likely to play, one in every two women likes plays video games as well (ENET, 2018a and 2018b).

ENet distinguishes between casual and hardcore gamers depending on the time spent playing. While three-quarters of video game players play at least once a week, they spend relatively little time playing these games. The most typical time spent playing a week is 1 to 2 hours (36\%) and 3 to 5 hours (25\%). Quarter of those playing weekly play up to one hour a week - typically those who play because boredom, waiting, or traveling.

The future generations seem to catch up as well, as near half of the under-18 age group (48\%) plays some type of videogame, with boys (57\%) still dominant over girls (35\%).

The numbers of the so called "hardcore gamers" (playing up to 20 hours a week) doubled up from 2016, when their numbers were estimated to be 200000 , in 2018 it is close to 425000 (ENET, 2019a). They are those playing esport games, and/or participate in competitions- and/or in esport events. $11 \%$ of the hardcore players can be considered as esport players with $92 \%$ male and only $8 \%$ female players.

Although the base of the national esport players is relatively small, there are still great results achieved from national esport players. The non-exhaustive list of some of the best Hungarian esport players and their suc-cesses are the following:

The half Hungarian professional esport player Jeromé "shiddy" Tóth achieved his biggest success in 2005 as a member of Team64. Shiddy is a CS 1.6 player who with his team won the first ever season of ESL, he also ended up on the podium nine times in the German Championship, and af- 
ter transferring to $n$ !faculty in 2008 won the French Migane Lan (LEET, 2019).

In 2018 Dániel Bereznay entered the narrow elite of best simulator Formu-la 1 drivers out of nearly 66000 riders. During the Series Bereznay was signed with the reigning champion Brendon Leight by Team Mercedes, and with an outstanding performance earned 2nd place behind Leight (LEET, 2019).

One of the most successful Hungarian esport player (LEET, 2019) the barely 18 years old Gábor "Gabihno" Szirtesi, who won 1st place in Fifa in the 2018 V4 Future Sports Festival. After winning first place he qualified to the FUT eWorld Cup playoff. In 2019 after winning the Ziggo eBattle Finals Gábor was signed by the Dutch esports organization AFC Ajax.

The best Hungarian LoL player, Tamás Kiss, known as Vizicsacsi is not only a prominent player in Hungary, he is also among the best toplaners on the international scene. In 2014, he qualified in the EU LCS with the Uni-corns of Love team (which other Hungarians have never succeeded in and since then no one has been able to repeat) (LEET, 2019).

By winning Asian dominated HoN Tour Season 3 World Finals "Fusen" Róbert Flick earned his championship title with his team Bad Monkey Gaming in 2015 (LEET, 2019).

Adrián "Raisy/Nofear" Birgány is known for his 2017 Quacke Champion-ship win in Denver.

Hungary's second best LoL player after Vizicsacsi is Dániel "Bluerzor" Subicz, whose first big team was the French GamersOrigin with which he won almost every French cup. After that he was signed by the Spanish team Movistar Riders (LEET, 2019).

Balázs Kodiak” Török was the member of the team $\mathrm{KO}$ who win the first ever World Cyber Game qualification in 2001. After switching to Counter Strike Source in 2005 Kodiak with his team finished WCG in 1st place again qualifying to travel to Singapore. Where the Hungarian team was ended up in the top eight. Later, they were invited to the European Championships, where they played the semi-finals (LEET, 2019).

One of the best and most popular female esport player in Hungary is Niko-lett "Nylon" Keszeli. Nikolett is a Counter Strike player, who ended up in 2nd place of the Electronic Sports World Cup in 2015 with her team and in 2016 they won the Intel Challenge Katowice (FLANCHER, 2019).

In terms of the esport players and teams 2017 was a turning point, as 5 esport departments were formed.

One of the very first is DVTK, sport club of Diósgyôr with the intent on forming teams, giving more opportunity to compete even on international scale. They were followed by MTK and the sports club of Debrecen: DVSC with their main focus on FIFA.

Honvéd's Lenovo Legion Honvéd Esport Academy entered the stage with the biggest capital in 2018.

A good example of the bottom up organization is from Debrecen as well, with the University of Debrecen Athletic Club's esports department the DEAC Hackers formed in 2017. Without budget their motivation was sole-ly the love of eports. Their main goals are to promote esports in Hungary and in University, to better understand the relationships between university sports life, competitive sports, interdisciplinary university research and electronic games, the game culture, exploration, accumulation and systema-tization of knowledge. Organizing the societal power of electronic games, supporting e-sports organizations with similar embeddedness, and in the long run, talent research and talent management in the region, and globally, "brain drain" to DEAC-Hackers, our university (DEAC, 2019).

\section{The Competitions}

Depending on its way of organization esport competitions can be catego-rized the following:

Bottom-up approach: This type is a mass-based competition. Teams get to the top of the list through qualifiers. The system itself does not involve any financial commitment for the teams, there is no entry fee. Anyone start in the qualifiers and through that, if he is talented enough, he can reach the top, giving each player motivation to compete (SZABELLA, 2018).

The Top-down approach: With the commercialization of esport Blizzard Entertainment launched its first Overwatch League to the shape of the American closed league traditional sport system. With this the aim was to combine full professionalism with e-sports and digital global promotion of sports (SZABELLA, 2018).

By the number of competitions esport competitions can be categorized into two groups as well.

Single competitions include only one event organized separately where players can compete to get a title.

Series where different events are held for different titles. These types of competitions have a lower prize pool than the single ones, but attract more viewers due to the different genres of the games.

By its nature esports competitions can be divided into Online competitions, whereas the name suggests players are registered and connected on online, and Offline competitions, where players are in the same place at the same time while competing against each other. These types of events have much higher costs due to traveling, accommodations and the virtual infrastruc-ture. Usually bigger Finals are held this way (SZABELLA, 2018).

From domestic circles there are two main events we would like to highlight. The first is the V4 Future Sport Festival, which was held in 2017 for the first time. Besides pointing out that there is a possibility for the countries of the region to organize successful esport events, the main goal was to bring international esport closer and to aim the focus on the possibilities of es-port (FLANCHER, 2019).

During the two days of the Festival players can compete in different games with the region's best teams. The two main games are the Counter Strike: Global Offensive and the Fortnite Battle Royale, but players can compete in games like FIFA, Tekken7 etc. as well.

The organization of the Festival is supported by the Hungarian Govern-ment.

The other main esport tournament is the Hungarian National Esport Cham-pionship (MNEB). 
One of the main differences between the two is, that MNEB is solely mar-ket based with its 15 million Huf prize pool thanks to sponsors like K\&H and Telekom (FLANCHER, 2019).

The competitions of the latest season were online based with only the fi-nals held offline. Where players and teams competed in LoL, CS: GO, PUBG, Hearthstone and Rainbow Six Siege.

MNEB held its first ever season from 14th of January to 30th of April 2019 and managed to get more than 700000 viewers to tune in to its finals in April.

\section{Sponsors}

190 million hours, the equivalent of 21700 years. That's the amount of time spent watching the four biggest esport tournaments in 2018. There is no question that the popularity of esport is rising drastically. Because of this reason in particular it is no surprise that with its business potential sponsors see it as a perfect marketing tool. The global marketing research firm Nielsen with its Esport24 system measured the value of sponsorship appearances in the finals of this year's biggest eSports championships. Ac-cording to the report, it fluctuated between \$ 75000 and \$ 17 million (ZSÉDELY, 2017), the later points out the opportunities and the overall picture of the fluctuation highlights the gap between this opportunity and the utilization of it. Another positive aspect of the use of esport as a mar-keting tool comes from the fact, that its consumers and their interests are very defined which makes them a really good target group for sponsors.

Although there is no exact data regarding the esport sponsorship in Hunga-ry the market research published by PricewaterhouseCoopers $(\mathrm{PwC})$ about Hungarian esports categorized revenue into 5 groups. From which sponsor-ship and advertising takes the biggest slice with almost 60 percent. While sponsors contribution to this is 360 million dollars globally, advertisements give 170 million to the budget (PWC, 2018).

As the biggest source of revenue sponsorship can be subdivided depending on whether to sponsoring players, teams or events. According to Pwc event sponsoring has the biggest cost of all, but is the safest, since player and team results vary too much, on the other hand sponsoring winners can pro-vide high returns for companies (PWC, 2018).

Because of the male dominated nature of esport brands targeting male au-diences use esport as a marketing tool (such as Gillette, Monster, Red Bull etc.) Besides them IT companies can benefit from esport the most, since from the estimated size of the Hungarian esport market in 2018 (24 billion Huf) the purchase of hardwares and peripheries account for the most of the spendings $(44.5 \%, 10.7$ billion Huf) (ENET, 2019a and 2019b).

\section{The Fans}

The size of the Hungarian esport market reached 23 billion huf in 2017. While in 2016 only one-fifth of domestic Internet users heard about e-sports, in 2017 this proportion had risen to one-third of the population aged 18-65 (ENET, 2018b).
As for the viewership of the competitions, the 2019 season finals of the Hungarian National Sports Championship were watched by 714715 , for more than 9.4 million minutes via the event's official stream channels with 412415 unique viewers (FLANCHER, 2019). It is without question that the national esport culture is rising.

According to the PwC's market report, those interested in esports are main-ly between the age of 18 and 34 (69\%), they are from mixed races, the average age is 28 , they have one or more smart electronic devices, and typically have high purchasing power (PWC, 2018).

\section{CONCLUSIONS}

With the lack of domestic literature regarding the Hungarian esport and with its drastic changes our main goal was to get an overall picture from economic prospect of the national esport ecosystem's situation.

From the actions of the last decade it is clear that Hungary see potential in the future of esport. There are clear efforts from both Governmental and from civil side as well.

As from the ecosystem can be seen Hungary is following the trends of the international esport market. The numbers of viewership and the players are rising steadily. New competitions and organizations are forming. The at-tempt to develop a stable structural base is with no doubt a huge step in to the right direction. But because of the specific nature of the esport players, for a small competitive player base to develop a large player pool is cru-cial.

With esport bars emerging country-wide, Sport Clubs forming esport de-partments and training gets more focus a rise in the quality of the Hungari-an esport is expected in the future.

\section{ACKNOWLEDGMENT}

The publication is supported by the EFOP-3.6.2-16-201700003 project. The project is co-financed by the European Union under the European Social Fund.

\section{REFERENCES}

Crawford G., Gosling V. (2009): More than a game: Sportsthemed video games \& player narratives. Sociology of Sport Journal, 26(1), 50-66

DEAC (2019): http://www.deac.hu/szakosztalyok/esport

ENet (2017): Közel 200.000. hazai e-sport játékos, az esport számokban https://enet.hu/hirek/kozel-200-000-hazai-e-sportjatekos-az-e-sportrol-szamokban/

ENet (2018a): E-sport: kevesek szórakozásából feltörekvő iparág, https://enet.hu/hirek/e-sport-kevesek-szorakozasabol-feltorekvo-iparag/

ENet (2018b): Magyarország 3,7 millió játékos hazája, http:// enet.hu/hirek/magyarorszag-37-millio-jatekos-hazaja/ 
ENet (2019a): A Magyar videojáték piac több mint felét az esport adja, https://enet.hu/hirek/a-magyar-videojatek-piac-tobbmint-felet-az-e-sport-adja/

ENet (2019b): Egyre többet költünk viedojátékra https://enet. hu/hirek/egyre-tobbet-koltunk-videojatekra/

European Sport Charter (1997): Article 2

Flancher B. (2019): Jöhet a magyar esportkánaán? https://index. hu/tech/godmode/2019/05/25/esport-mneb-hunesz-verseny-v4future-sports-magyar/ 2019.09.13.

HUNESZ (2018): MNEB Versenkyiírás, https://hunesz.hu/ documents/Magyar-Nemzeti-E-sport-Bajnoksag-versenykiiras2018-2019-ideny_2.pdf 2019.08.27.

Impey S. (2018): Most-watched esports events record $190.1 \mathrm{~m}$ streaming hours. http://www.sportspromedia.com/news/esports-tournaments-record-live-streaming-hours 2019.07.25.

Leet (2019): A magyar esport történelem legnagyobb sikerei https://leet.hu/2019/07/24/osszegyujtottuk-nektek-hazank-esporttortenelmenek-legkiemelkedobb-alakjait-es-eredmenyeiket/

Needleman SE. (2015): “Twitch's Viewers Reach 100 Million a Month", The Wall Street Journal, https://www.wsj. com/articles/facebook-embraces-esports-in-its-video-strategyshift1495099801 2019.10.01.

Needleman SE., Seetharaman D. (2017): "Facebook Embraces Esports in Its Video Strategy Shift", The Wall Street Journal, https://www.wsj.com/articles/facebook-embracesesports-in-itsvideo-strategy-shift-1495099801 2019.08.14.

Newzoo (2017): White Paper: An Overview of Esports in Europe

Noyes D. (2019): The Top 20 Valuable Facebook Statistics, https://zephoria.com/top-15-valuable-facebook-statistics/ 2019.10.01.

Olsen AH. (2015): The evolution of eSports: an analysis of its origin and a look at its prospective future growth as enhanced by Information Technol-ogy Management tools. arXiv preprint arXiv:1509.08795.

Pannekeet, J. (2019): More People Are Streaming on Twitch, But YouTube Is the Platform of Choice for Mobile-Game Streamers https://newzoo.com/insights/articles/more-peopleare-streaming-on-twitch-but-youtube-is-the-platform-of-choicefor-mobile-game-streamers/ 2019.09.29.

PwC (2018): Az e-sport nem játék, Üzleti elemzés Magyarország és a V4-ek e-sport-piacáról, https://www.pwc.com/hu/hu/ kiadvanyok/assets/pdf/esport.pdf 2019.08.23.
Szabella, O. (2018): Korunk virágzó biznisze? Az e-sport iparág be-mutatása, Információs Társadalom, XVIII(1) pp. 66-92.

Zsédely, P. (2017): Mennyit ér a szponzoráció az eSportban? A Nielsen felméri! http://sportsmarketing.hu/2017/08/24/mennyiter-a-szponzoracio-az-esportban-a-nielsen-felmeri/ 2019.10.02. 